\title{
ADDITIONAL INFILTRATION TO UNDERGROUND WATERS OF BIG CITIES TERRITORY (FOR EXAMPLE KHARKIV REGIONE)
}

\author{
Olena Sierikova \\ Valeriy Yakovlev
}

Kharkiv National Academy of Municipal Economy, Ukraine

\begin{abstract}
The paper treats issue of additional technogenic recharge of underground waters of typical industrial city Kharkiv. Base of quantity identification is statistical data of water supply system and canalization at the city. Aim is to estimate additional infiltration influence to groundwater level rising and qualitative composition of them.
\end{abstract}

\section{KEYWORDS}

Groundwater level, groundwater recharge, additional infiltration, leakages, drinking-water supply system, underflooding.

\section{INTRODUCTION}

The Kharkiv city takes 24 place in Ukraine of water availability and is located in forest-steppe area of water shortage. The city is arranged in the River Siversky Donets basin at the confluence of the Udi, Lopan and Kharkiv. Kharkiv territory is characterized of building inhomogeneity, different conditions of land use, presence of multi-functional zones such as residential, industrial, green, storage zones and presence of numerous transport routes and engineering communications. Building type (multi-storey, one-storey, old, new), engineering networks schemes, relief organization, landscaping, gardening and building density have been presented within each functional zone. Given the diversity of geofiltration structure of the urban area, should be expecting significant heterogeneity of water exchange.

Depth of underground space development within the city territory is tens or hundreds of meters. Upper level under treatment covers the interval 0-10 m. Underground parts of most houses and buildings of industrial and civil objects, engineering networks and drainage systems equipment have been located at the level. The part in question differentiates by distribution maximum amplitudes of seasonal and long-term fluctuations of humidity, temperature, hydrodynamic, and other indicators. Adverse geological process development including underflooding, inundation, subsidence, suffosion, the formation of corrosive environment due to the zone under elucidation. [2,3].

\section{DISCUSSIONS}

Intensity of the additional infiltration is one of the significant indicators of water exchange process formation of urban territories. Impact factors of additional infiltration have been treated for additional infiltration influence evaluation for groundwater level changing and 
groundwater quality. Currently, 510 cities and villages have been underflooded causing necessary and valid position of elucidation the factors of additional infiltration.

The factors causing additional infiltration to groundwaters of urban territories are following:

1. Technogenic leakages (losses) of different networks of water communications;

2. Remodelling of the earth's surface and breach of surface runoff conditions (rising of the carriageway of roads, railway embankments, intensive building, etc.)

3. The absence, failure of storm sewers; leakages from reservoirs;

4. Barrage impact of underground facilities;

5. Water balance changes caused by technogenic covers. [4].

Magnitudes of natural and additional infiltration have been comparing.

Annual precipitation is $525 \mathrm{~mm} /$ year of Kharkiv regional center of hydrometeorology data on climatic conditions characteristic. The quantity of precipitation infiltration to groundwaters is $114 \mathrm{~mm} /$ year $\left(31,2 \cdot 10^{-5} \mathrm{~m} /\right.$ day; 35302,8 thousand $\mathrm{m}^{3} /$ year $)$. [2,3,5].

Leakages data of Kharkiv drinking-water supply system according to the statistic data of water supply company "Water" have been presented at the table 1 .

\begin{tabular}{|c|c|c|c|c|c|c|}
\hline \multirow{2}{*}{} & \multicolumn{3}{|c|}{2005} & \multicolumn{2}{c|}{2006} \\
\cline { 2 - 4 } & $\begin{array}{c}\text { Water } \\
\text { intake, } \\
\text { thousand } \\
\mathrm{m}^{3} / \mathrm{year}\end{array}$ & $\begin{array}{c}\text { thousand } \\
\mathrm{m}^{3} / \text { year }\end{array}$ & $\%$ & $\begin{array}{c}\text { Water } \\
\text { intake, } \\
\text { thousand } \\
\mathrm{m}^{3} / \text { year }\end{array}$ & $\begin{array}{c}\text { Leakages } \\
\mathrm{m}^{3} / \mathrm{year}\end{array}$ & $\%$ \\
\hline $\begin{array}{c}\text { Krasnopavlovskoe } \\
\text { reservoir }\end{array}$ & 58688,8 & 23697,6 & 40,38 & 59269,6 & 23195,6 & 39,14 \\
\hline $\begin{array}{c}\text { Siverskiy Donets } \\
\text { river }\end{array}$ & 197978,2 & 81317,9 & 41,07 & 197165,4 & 78146,0 & 39,63 \\
\hline Artesian wells & 6314,3 & 2582,4 & 40,9 & 3438,1 & 1409,3 & 40,99 \\
\hline
\end{tabular}

Table 1. Water intake and leakages according to the statistic data of water supply company "Water", m3/year [1].

Consequently, quantity of leakages of drinking-water supply system is $40 \%(105174,4$ thousand $\mathrm{m}^{3} /$ year) of the water supplied volume to the city. Quantity of leakages of canalization system is $20 \%$ of the water supplied volume to the city. Further, half of drinkingwater supply system leakages are losses of heating networks. The sum of leakages is 210348,8 thousand $\mathrm{m}^{3} /$ year. $[1,6]$

Outcomes of comparing magnitudes of natural and additional infiltration have been revealed excess over the natural infiltration of technogenic in 6 times. Hence, additional infiltration is a lead factor of groundwater recharge in the big cities and causing increasing groundwater level, underflooding significant part of city territory.

Underflooding of city territory is causing appearance marshy areas and flooded underground rooms in the houses and destroys underground communications materials. It is lead to appearance mosquitoes, the development of fungi, poisonous fumes in the air and harmful impacting on human health and to significant material losses. Moreover, accident on sewer 
systems and increased infiltration from the surface resulted to significant contamination of the upper layers of groundwater, and their unsuitability for drinking water consumption.

The interaction between groundwaters and buildings fundaments and engineering complexes of city significantly influence on it stability and reliability. Groundwater level changing leads to changing geotechnical properties of bases and causes changes of land biocenoses and conditions of human life.

Underflooding process causes and activates a number of dangerous geological processes, including landslides, suffusion, karst and leaching. [4,6].

\section{CONCLUSIONS}

Outcomes of comparing magnitudes of natural and additional infiltration have been revealed excess over the natural infiltration of technogenic in 6 times. Hence, additional infiltration is a lead factor of groundwater recharge in the big cities and causing increasing groundwater level, underflooding significant part of city territory.

Besides, additional infiltration is valid factor of groundwaters qualitative composition impacting. Water of technogenic origin getting to the groundwater as an additional infiltration almost completely changes their qualitative composition of natural to technogenic.

\section{REFERENCES}

[1] Statistic data of water supply company "Water"

[2] Working project "Engineering protection of flooding the territory of trade-service complex with objects of cultural and entertainment destination on the Ac. Pavlova street of Kharkiv". 2007.

[3] Working project "The pond creation of the territory of trade-service complex with objects of cultural and entertainment destination on the Ac. Pavlova street of Kharkiv". 2008.

[4] Strigelchik G., Sokolov Y., Goldfeld I., Chebanov A., Nikolenko N. Underflooding at the urban settlements of Kharkiv region. - Kharkiv, 2003. 160 p.

[5] Strelets B. Handbook of water resources. - K., 1987. 302p.

[6] Howard K. Urban groundwater - meeting the challenge. 307p. 